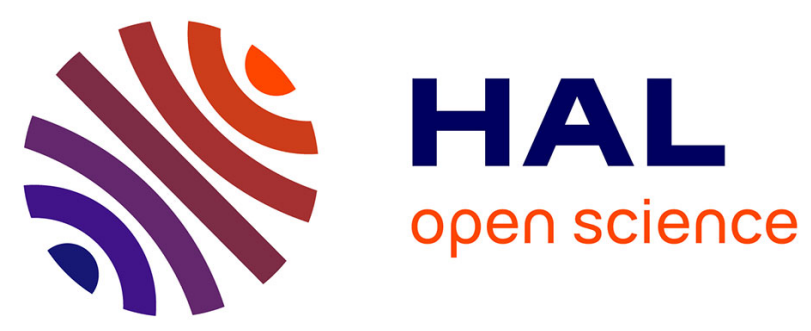

\title{
Microwave-assisted efficient synthesis of 1,2-diaryldiketones: a novel oxidation reaction of diarylalkynes with DMSO promoted by FeBr3
}

Anne Giraud, Olivier Provot, Jean-François Peyrat, Mouad Alami, Jean-Daniel Brion

\section{To cite this version:}

Anne Giraud, Olivier Provot, Jean-François Peyrat, Mouad Alami, Jean-Daniel Brion. Microwaveassisted efficient synthesis of 1,2-diaryldiketones: a novel oxidation reaction of diarylalkynes with DMSO promoted by FeBr3. Tetrahedron, 2006, 62 (33), pp.7667-7673. 10.1016/j.tet.2006.05.072 . hal-02394615

\section{HAL Id: hal-02394615 \\ https://hal.science/hal-02394615}

Submitted on 4 Dec 2019

HAL is a multi-disciplinary open access archive for the deposit and dissemination of scientific research documents, whether they are published or not. The documents may come from teaching and research institutions in France or abroad, or from public or private research centers.
L'archive ouverte pluridisciplinaire HAL, est destinée au dépôt et à la diffusion de documents scientifiques de niveau recherche, publiés ou non, émanant des établissements d'enseignement et de recherche français ou étrangers, des laboratoires publics ou privés. 


\section{Microwave-assisted efficient synthesis of 1,2-diaryldiketones: a novel oxidation reaction of diarylalkynes with DMSO promoted by FeBr3}

Anne Giraud, Olivier Provot, Jean-François Peyrat, Mouad Alami, Jean-Daniel Brion

\section{To cite this version:}

Anne Giraud, Olivier Provot, Jean-François Peyrat, Mouad Alami, Jean-Daniel Brion. Microwaveassisted efficient synthesis of 1,2-diaryldiketones: a novel oxidation reaction of diarylalkynes with DMSO promoted by FeBr3. Tetrahedron, Elsevier, 2006, 62 (33), pp.7667-7673. 10.1016/j.tet.2006.05.072 . hal-02394615

\section{HAL Id: hal-02394615 \\ https://hal.archives-ouvertes.fr/hal-02394615}

Submitted on 4 Dec 2019

HAL is a multi-disciplinary open access archive for the deposit and dissemination of scientific research documents, whether they are published or not. The documents may come from teaching and research institutions in France or abroad, or from public or private research centers.
L'archive ouverte pluridisciplinaire HAL, est destinée au dépôt et à la diffusion de documents scientifiques de niveau recherche, publiés ou non, émanant des établissements d'enseignement et de recherche français ou étrangers, des laboratoires publics ou privés. 


\title{
Microwave-assisted an efficient synthesis of 1,2 diaryldiketones: A novel oxidation reaction of diarylalkynes with DMSO promoted by $\mathrm{FeBr}_{3}$
}

\author{
Anne Giraud, Olivier Provot ${ }^{*}$, Jean-François Peyrat, Mouâd Alami* and Jean-Daniel Brion \\ Laboratoire de Chimie Thérapeutique, BioCIS-CNRS (UMR 8076), Université Paris-Sud, Faculté de Pharmacie, rue J.B. Clément 92296 \\ Châtenay-Malabry Cedex, France
}

\begin{abstract}
This paper reports the oxidation of functionalized-diarylalkynes with DMSO in the presence of the environmentally friendly $\mathrm{FeBr}_{3}$ catalyst. This non-toxic procedure is general and has been applied successfully under microwaves irradiation leading rapidly to benzil derivatives in good yields
\end{abstract}

\section{Introduction}

Benzil derivatives are an important class of compounds which have been reported for their application as inhibitors of the acid corrosion of mild steel, ${ }^{1}$ as photosensitives agents in photocurable coatings, ${ }^{2}$ and also as natural compounds. ${ }^{3}$ Moreover, benzil substrates constitute useful intermediates in organic synthesis as precursors of various heterocyclic compounds such as for example imidazoles ${ }^{4}$ or quinoxalines. ${ }^{5}$ Conventionally, benzils derivatives are obtained by oxidation of benzoins, ${ }^{6}$ or hydrobenzoins. ${ }^{7}$ However, the access to functionalized benzoins is not easy and their oxidation very often required the use of toxic and/or expensive reagents (e.g. thallium nitrate, ${ }^{6 \mathrm{~d}}$ ammonium chlorochromate-alumina, ${ }^{6 \mathrm{e}}$ $\mathrm{RuO}_{4},{ }^{6 \mathrm{~g}} \mathrm{~N}$-hydroxyphtalimide-Co(acac) $\left.)_{3}\right){ }^{7 \mathrm{c}}$ Beside other methodologies, $8,6 \mathrm{~g}$ by far the most important procedure for the preparation of benzils is the oxidation of diarylalkynes which are easily prepared by Sonogashira-Linstrumelle coupling. Thus, a large number of oxidizing systems have been utilized including, $\mathrm{Co}(\mathrm{OAc})_{2} / \mathrm{Mn}(\mathrm{OAc})_{2} / \mathrm{NaBr},{ }^{9}$ $\mathrm{ZnCr}_{2} \mathrm{O}_{7} .3 \mathrm{H}_{2} \mathrm{O},{ }^{10} \mathrm{SO}_{3}$-dioxane complex, ${ }^{11} \mathrm{H}_{5} \mathrm{IO}_{6},{ }^{12}$ and $\mathrm{CH}_{3} \mathrm{ReO}_{3} / \mathrm{H}_{2} \mathrm{O}_{2}$. ${ }^{13}$ However, these reagents have several drawbacks in term of toxicity, difficult reaction *Keywords : Benzils; DMSO; Iron bromide; alkynes, microwaves irradiation. *Corresponding authors:

(O.P.) tel.: +33 14683 5847; fax: +33 14683 5828;

olivier.provot@cep.u-psud.fr

(M.A.) tel.: +33 14683 5887; fax: +33 14683 5828;

mouad.alami@cep.u-psud.fr conditions, long reaction times and/or low yields. DMSO as oxidant in the presence of an excess of $\mathrm{NBS}^{14}$ has been successfully reported to transform diphenylacetylene into benzil. Similary, an attractive protocol using DMSO as oxidant in the presence of $\mathrm{PdCl}_{2}$ has been described by a Russian team. ${ }^{15}$ While this transformation is a suitable method, its success was influenced by the electronic nature of the aryl-substituents. ${ }^{16} \mathrm{~A}$ recent work concerning the oxidation of alkynes into $\alpha$-diketones with DMSO and $\mathrm{CH}_{3} \mathrm{SO}_{3} \mathrm{H} / \mathrm{HCO}_{2} \mathrm{H} / \mathrm{HBr}^{17}$ prompted us to report the results of our study. With respect to the environmental concerns, there is a strong demand for a clean, safe and highly efficient catalytic methodology for the conversion of aryl alkynes to benzil derivatives.

\section{Results and discussion}

As a part of our programme aimed at the development of new, soft and selective oxidizing methodologies, ${ }^{18}$ we have investigated the oxidation of various internal aryl alkynes 1 with DMSO in the presence of catalytic amounts of friendly transition-metal salts. Herein, we report a simple and convenient procedure for the synthesis of a range of functionalized benzil derivatives promoted by the non-toxic and cheap $\mathrm{FeBr}_{3}$. 
At the out set of this work, we began our approach by screening a variety of catalysts using the diaryl alkyne 1a as model substrate in DMSO.

Table 1 Oxidation of diarylalkyne $\mathbf{1 a}$ to benzil $\mathbf{2 a}$

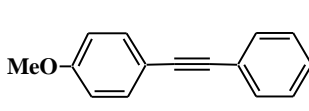

$1 \mathbf{a}$

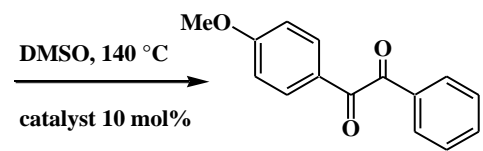

2a

\begin{tabular}{cccc}
\hline \hline Entry & Catalyst & Time (h) & Yield $^{\mathrm{a}}(\boldsymbol{\%})$ \\
\hline \hline 1 & - & 72 & 0 \\
2 & $\mathrm{CuCl}$ & 72 & 65 \\
3 & $\mathrm{CuBr}$ & 72 & 66 \\
4 & $\mathrm{InCl}_{3}$ & 16 & 65 \\
5 & $\mathrm{InBr}_{3}$ & 14 & 70 \\
6 & $\mathrm{NiCl}_{2}$ & 40 & 72 \\
7 & $\mathrm{NiBr}_{2}$ & 24 & 76 \\
8 & $\mathrm{MnCl}_{2}$ & 36 & $0^{\mathrm{b}}$ \\
9 & $\mathrm{MnBr}_{2}$ & 14 & $75^{\mathrm{b}}$ \\
10 & $\left.\mathrm{Fe}^{\mathrm{acac}}\right)_{3}$ & 40 & 68 \\
11 & $\mathrm{FeCl}_{3}$ & 36 & 73 \\
12 & $\mathrm{FeBr}_{3}$ & 10 & 80 \\
13 & $\mathrm{FeBr}_{3}{ }^{\mathrm{c}}$ & 10 & 78 \\
\hline \hline
\end{tabular}

a isolated yield.

b Two reproducible attempts.

c 1 equiv of $\mathrm{FeBr}_{3}$ was used.

The results described in Table 1 , showed clearly that transition metal catalysts promoted the oxidation of 1a while no reaction occurred without catalyst (entry 1). Whereas all studied metal salts (bromides or chlorides) were effective in a surprising way, $\mathrm{MnCl}_{2}$ (2 attempts) did not catalyse the oxidation reaction (entry 8) and starting alkyne 1a was recovered unchanged. Examination of Table 1 indicates that transition-metal salts bromides catalysts were superiors to the corresponding chlorides in term of increasing yields and reducing reaction times. In all studied cases, no traces of aryl alkyne 1a were found at the end of the reaction and then purifications were easy. Of the transition-metal salts examined, $\mathrm{FeBr}_{3}$ was the most efficient catalyst delivering benzil $\mathbf{2 a}$ in high yield
( $10 \mathrm{~h}, 80 \%$, entry 12$)$ whereas, under the same conditions $\mathrm{FeCl}_{3}$ and $\mathrm{Fe}(\mathrm{acac})_{3}$ gave similar yields but with longer reaction times (entries 10 and 11 ). With $\mathrm{CuBr}, \mathrm{InBr}_{3}$, $\mathrm{NiBr}_{2}$ and $\mathrm{MnBr}_{2}$ the oxidation reaction was also successful but with lower yields and longer reaction times (entries 3, 5, 7, 9). Finally, increasing the amount of the iron bromide catalyst was not efficient to observe neither a reduced reaction time nor a better yield (entry 13).

In our current work to develop rapid and efficient methods for oxidation reactions, we thought to speed up the synthesis of various benzils using microwavesassisted irradiation. ${ }^{18 \mathrm{~d}}$

Our first efforts were focused on the optimization of the reactional temperature. When the reaction of $1 \mathbf{a}$ is carried out at $140^{\circ} \mathrm{C}$ (as base line control to evaluate the microwaves contribution) for 20 minutes, one notes that $20 \%$ of the starting product $\mathbf{1 a}$ was transformed into its corresponding benzil $\mathbf{2 a}$, while only traces of $\mathbf{2 a}(<5 \%$, indicated by GC) were obtained by conventional thermal conditions. By increasing gradually the reactional temperature, we were pleased to observe that, using microwave irradiation at $200^{\circ} \mathrm{C}$, diarylalkyne 1 a was totally transformed into $\mathbf{2 a}$ in only 20 minutes and with a satisfactory yield $(75 \%) .{ }^{19}$ It should be noted that under convention thermal heating $\left(200^{\circ} \mathrm{C}, 20 \mathrm{~min}\right.$, scelled tube) the reaction occured smoothly and $50 \%$ of starting material was recovered unchanged. $\mathrm{InBr}_{3}(10 \mathrm{~mol} \%)$ and $\mathrm{MnBr}_{2}(10 \mathrm{~mol} \%)$ were also tested, but longer reaction times, by comparison with $\mathrm{FeBr}_{3}$, were required to oxidize completely 1a $(75 \%, 40 \mathrm{~min}$ and $68 \%, 45 \mathrm{~min}$ respectively).

Next, we investigated the oxidizing species. When using stoichiometric amounts or slight excess (5 equiv.) of DMSO, no traces of $\mathbf{2 a}$ were detected even after a prolongated reaction time $(48 \mathrm{~h})$. A similar result was obtained when DMSO was replaced by Sulfolane (tetramethylene sulfone); the oxidation reaction failed and starting alkyne 1a was recovered unchanged. We are presently examining alternatives to DMSO for the oxygen transfer step.

To demonstrate the scope of the reaction, a series of acetylenic substrates 1a-o were synthesized by Sonogashira-Linstrumelle coupling ${ }^{20}$ and subjected to oxidation by the $\mathrm{DMSO}-\mathrm{FeBr}_{3}$ couple under microwaves irradiation. The results of this study are summarized in Table 2 .

Table 2. Oxidation of diarylalkynes $\mathbf{1}$ to benzyl derivatives $\mathbf{2}$ under microwaves irradiation

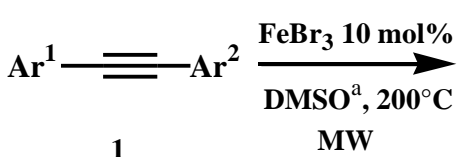<smiles>O=C([AlH2])C(=O)[AlH2]</smiles> 
Tetrahedron

\begin{tabular}{|c|c|c|c|c|c|c|}
\hline & & & & & & \\
\hline Entry & Akynes & 1 & Benzils & 2 & $\begin{array}{l}\text { Time } \\
\text { (min) }\end{array}$ & $\begin{array}{c}\text { Yield }^{\mathrm{b}} \\
(\%)\end{array}$ \\
\hline 1 & & 1a & & $2 a$ & 20 & $75^{c}$ \\
\hline 2 & & $1 b$ & & $2 b$ & 40 & 70 \\
\hline 3 & & $1 c$ & & $2 c$ & 9 & 75 \\
\hline 4 & & 1d & & $2 d$ & 25 & 64 \\
\hline 5 & & $\mathbf{1 e}$ & & $2 e$ & 30 & 65 \\
\hline 6 & & 1f & & $2 f$ & 11 & 61 \\
\hline 7 & & $1 \mathrm{~g}$ & & $2 \mathrm{~g}$ & 20 & 73 \\
\hline 8 & & $1 \mathrm{~h}$ & & $2 h$ & 9 & 75 \\
\hline 9 & & $1 \mathrm{i}$ & & $2 \mathrm{i}$ & 9 & 72 \\
\hline 10 & & $\mathbf{1 j}$ & & $2 j$ & 15 & 72 \\
\hline 11 & & $1 k$ & & $2 k$ & 21 & 46 \\
\hline 12 & & 11 & & 21 & 16 & 43 \\
\hline 13 & & $1 \mathrm{~m}$ & & $2 m$ & 120 & 0 \\
\hline 14 & & 1n & & $2 m$ & 9 & 51 \\
\hline 15 & & 10 & & 20 & 8 & 59 \\
\hline
\end{tabular}

${ }^{\mathrm{a}}$ During this study, we did not observe a notable degradation of the $\mathrm{DMSO}^{21}$ under microwaves irradiation.

${ }^{\mathrm{b}}$ Isolated yield. All compounds exhibited satisfactory spectral properties and microanalyses.

${ }^{\mathrm{c}}$ No oxidation was observed when reactions were conducted without $\mathrm{FeBr}_{3}$ in $\mathrm{DMSO}$ at $200^{\circ} \mathrm{C}$ under MWI.

Arylalkynes substituted with an electron-donating group (Me, OMe) have been transformed into benzil derivatives in good yields (from $61 \%$ to $76 \%$ ) and with reduced reaction times $(<1 \mathrm{~h})$. It should be noted that the position of the substituent $(o, m, p)$ on the aromatic ring had no influence on the oxidation yield, although the meta benzil 2c was obtained in a shorter reaction time (compare entry 3 with entries 1 and 2). We were also pleased to observe that halogenated substituted arylalkynes $\mathbf{1 h}$ and $\mathbf{1 i}$ afforded the expected benzils with reduced times and good yields $(<10$ min., 72-75\%, entries 8 and 9). Moreover, the presence of an electron withdrawing group on the aryl ring such as $\mathrm{NO}_{2}$ did not affect the yield as well as the reaction time of the oxidizing process and provides benzil $\mathbf{2} \mathbf{j}$ in $72 \%$ yield 
(entry 10). However, by using arylalkynes $\mathbf{1 k}$ and $\mathbf{1 l}$ substituted with an ortho or a para cyano group respectively, the desired corresponding benzil derivatives $\mathbf{2 k}$ and $\mathbf{2 l}$ were obtained in moderate yields although totally disappearance of starting material was observed. It seems that under these conditions the cyano group interfer with the outcome of the present reaction (non-identified hydrolyzed by-products were observed in the crude reaction mixture). One can note that the phenolic aryl alkyne $\mathbf{1 m}$ did not give its corresponding benzil $\mathbf{2 m}$, even after a prolongated reaction time under MW irradiation. However, when the hydroxy substituent of $\mathbf{1 m}$ was protected as an acetate (1n), we observed the formation of $\mathbf{2 m}$, after oxidation of the triple bond followed by cleavage of the acetoxyester group. A similar result (oxidation and cleavage) has been obtained with conventional heating (70\%, $7 \mathrm{~h}$ ). On the contrary, pivaloyl substituted ester 10 was successfully transformed into its corresponding benzil 2o, but without removal of the bulky, protecting group (entry 15). It is important to note that this new oxidation process with $\mathrm{FeBr}_{3}$-DMSO is not sensitive to the electronic nature of the acetylenic substrates, unlike some others methodologies. ${ }^{11}$

\section{Mechanistic consideration}

At first, an experiment was performed in which the DMSO solution was degazed. Whithout $\mathrm{O}_{2}$, oxidation of $\mathbf{1 a}$ was still observed with comparable yields and reaction times, implying that DMSO constitutes the oxidizing species. When 1a was heated in DMSO without any catalysts, the oxidation occurred slowly (stirring for $72 \mathrm{~h}$ at $140^{\circ} \mathrm{C}$, starting alkyne 1a $(10 \%)$ was still recovered). In the plausible proposed mechanism (Scheme 1) concerning the oxidation of arylalkynes $\mathbf{1}$, the Fe(III), acting as a Lewis acid, may activate the triple bond to generate $\mathbf{I}$ and allowed successive additions of DMSO. After a first addition, a vinyl iron species II (or its cationic equivalent) would be formed and then trapped by a second molecule of DMSO. The species III formed would evolve to afford the desired benzyl 2 together with $\mathrm{Me}_{2} \mathrm{~S}$ and regenerated the catalyst.

In order to better activate the alkyne function, the Lewis acidity of the Fe(III)-catalyst should be increased. For that purpose, an additional experiment was achieved by introducing $30 \mathrm{~mol} \%$ of trifluoromethanesulfonic acid (TfOH) to the reaction mixture (1a, $10 \mathrm{~mol} \%$ of $\mathrm{FeBr}_{3}$, DMSO). We were pleased to observe, that under classical thermal conditions $\left(140{ }^{\circ} \mathrm{C}\right)$, the oxidation proceeded in only $1 \mathrm{~h}$ and with a good yield $(71 \%)$. In order to determine the positive influence of $\mathrm{TfOH}$ associated with $\mathrm{FeBr}_{3}$, we performed the oxidation without $\mathrm{FeBr}_{3}$, as control. Total disappearance of $\mathbf{1 a}$ was observed but after $10 \mathrm{~h}$ of reaction. It is reasonable to think that the catalytic species formed $\mathrm{Fe}(\mathrm{OTf})_{3},{ }^{22}$ which is a stronger Lewis acid than $\mathrm{FeBr}_{3}$, activates considerably the triple bond. Other attempts were achieved with various iodine salts in place of $\mathrm{TfOH}$ but unfortunatelly failed to give $\mathbf{2 a}$ in shorter reaction times. This latest oxidation reaction involving the synergetic couple $\mathrm{TfOH}$ and $\mathrm{FeBr}_{3}$ is currently under investigation in our Laboratory.

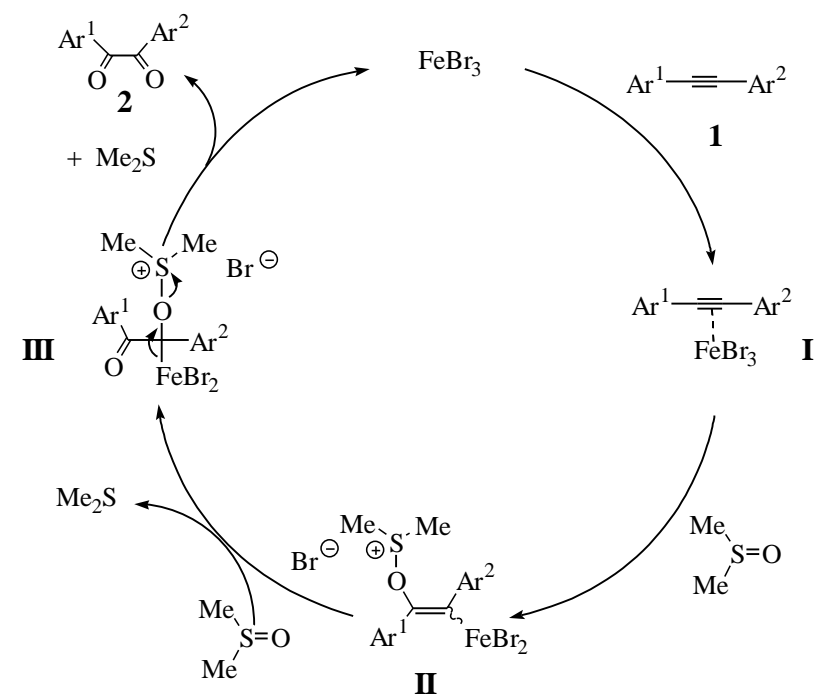

Scheme 1: Proposed pathway for the oxidation of arylalkynes $\mathbf{1}$.

\section{Conclusion}

In conclusion, we have developed a simple and efficient process for oxidation of aryl alkynes using DMSO and catalytic $\mathrm{FeBr}_{3}$. The use of friendly non-toxic catalytic $\mathrm{FeBr}_{3}$, short reaction times, high to excellent yields, low coast and easy preparation are the obvious advantages of the present method. Under classical thermal conditions, we have demonstrated that the tandem $\mathrm{FeBr}_{3}$-DMSO can be used to prepare benzil derivatives in reasonable reaction times and satisfactory yields. The microwave-assisted procedure allows for the rapid synthesis of various benzils, $20 \mathrm{~min}$ compared to $10 \mathrm{~h}$ by conventional methods. The experimental microwaves experiments described in this paper are well established and controlled and can be safely and beneficially reproduced.

\section{Experimental}

\subsection{Materials}

All glasswares were oven-dried at $140{ }^{\circ} \mathrm{C}$ and all reactions were conducted under an argon atmosphere. Tetrahydrofuran (THF) was distilled from sodiumbenzophenone ketyl. Triethylamine (TEA) was distilled from potassium hydroxide under argon prior to use.

\subsection{Instrumentation}

All microwave experiments were performed using an Emrys Optimizer in 2-5 mL pyrex reaction vessels. Each 
contained a Teflon stir bar and Teflon coated reaction vessel cap.

The compounds were all identified by usual physical methods, i.e. ${ }^{1} \mathrm{H}-\mathrm{NMR},{ }^{13} \mathrm{C}-\mathrm{NMR}$, IR and elemental analysis. ${ }^{1} \mathrm{H}$ and ${ }^{13} \mathrm{C}$ NMR spectra were measured in $\mathrm{CDCl}_{3}$ with a Bruker AC 200 or Bruker ARX 400. ${ }^{1} \mathrm{H}$ chemical shifts are reported in ppm from an internal standard TMS or of residual chloroform $(7.27 \mathrm{ppm})$. The following abreviation are used : $m$ (multiplet), s (singlet), d (doublet), $\mathrm{t}$ (triplet), dd (doublet of doublet), tt (triplet of triplet). ${ }^{13} \mathrm{C}$ chemical shifts are reported in ppm from the central peak of deuteriochloroform (77.14). IR spectra were measured on a Bruker Vector 22 spectrophotometer (neat, $\mathrm{cm}^{-1}$ ). Elemental analyses were performed with a Perkin-Elmer 240 analyser. Mass spectra were obtained with a LCT Micromass spectrometer. Analytical TLC were performed on Merck precoated silica gel $60 \mathrm{~F}$ plates. Merck silica gel 60 (230-400 mesh) was used for column chromatography. Melting points (m.p.) were recorded on a Büchi B-450 apparatus and were uncorrected.

\subsection{General procedure for the preparation of aryl alkynes from aryl halides}

All aryl alkynes exept 10 were known compounds and have been prepared according to the following procedure:

\section{2,2-Diethyl-propionic acid 4-phenylethynyl-phenyl ester 10}

To a mixture of 2,2 Dimethyl-propionic acid-4-iodo-phenyl ester $(303 \mathrm{mg} ; 1 \mathrm{mmol}), \mathrm{PdCl}_{2}\left(\mathrm{PPh}_{3}\right)_{2} \quad(35.1 \mathrm{mg} ; 0.05$ mmol), CuI (19.1 mg; $0.1 \mathrm{mmol}$ ), TEA (404.8 mg; 4.0 $\mathrm{mmol})$ in THF $(10 \mathrm{~mL})$ was added dropwise under an argon atmosphere, a solution of phenylacetylene (132.6 mg; 1.2 $\mathrm{mmol})$. The mixture was stirred at room temperature for a night. Then $\mathrm{Et}_{2} \mathrm{O}(20 \mathrm{~mL})$ was added to the crude and the mixture was filtered over a short pad of celite. The organic layer was washed with brine $(5 \mathrm{~mL})$ twice, separated, dried over $\mathrm{MgSO}_{4}$, filtered, and concentrated. Resulting residue was further purified by flash chromatography.

Yield: $95 \%$

m.p.: $92{ }^{\circ} \mathrm{C}$

TLC: $\mathrm{R}_{\mathrm{f}} 0.61$ (Cyclohexane/EtOAc, 90/ 10, $\mathrm{SiO}_{2}$ )

Anal. Calcd for $\mathrm{C}_{19} \mathrm{H}_{18} \mathrm{O}_{2}$ : C, 81.99; H, $6.52 \%$; Found: C, $81.87 ; \mathrm{H}, 6.47$.

IR (neat) $v_{\max } / \mathrm{cm}^{-1}: 2971,1743,1593,1506,1479,1445$, 1396, 1369, 1275, 1235, 1197, 1160, 1140, 1115, 1033, 1013, 954, 919, 897, 859, 842, 801.

${ }^{1} \mathrm{H}$ NMR for $10\left(\mathrm{CDCl}_{3}, 200 \mathrm{MHz}, 298 \mathrm{~K}\right): \delta$, ppm 7.62$7.51(\mathrm{~m}, 4 \mathrm{H}), 7.36-7.33(\mathrm{~m}, 3 \mathrm{H}), 7.06(\mathrm{~d}, 2 \mathrm{H}, J=8.7 \mathrm{~Hz})$, $1.37(\mathrm{~s}, 9 \mathrm{H})$.

${ }^{13} \mathrm{C}$ NMR for $10\left(\mathrm{CDCl}_{3}, 50 \mathrm{MHz}, 298 \mathrm{~K}\right): \delta$, ppm 176.7 (CO), $151.0(\mathrm{C}), 132.7(2 \mathrm{CH}), 131.6(2 \mathrm{CH}), 128.3(2 \mathrm{CH})$, $128.3(\mathrm{CH}), 123.2(\mathrm{C}), 121.6(2 \mathrm{CH}), 120.7(\mathrm{C}), 89.3(\mathrm{C})$, $88.6(\mathrm{C}), 39.1(\mathrm{C}), 27.1\left(3 \mathrm{CH}_{3}\right)$.
5.4. General procedure for thepreparation of benzils 2a-o from alkynes under microwaves irradiation

To an Emrys Optimizer 2-5 $\mathrm{mL}$ pyrex reaction vessel were added alkyne $(0.5 \mathrm{mmol}), \mathrm{FeBr}_{3}(15 \mathrm{mg} ; 0.05 \mathrm{mmol})$, in DMSO $(2.5 \mathrm{~mL})$. The reaction vessel was then placed in the Emrys Optimizer and exposed to microwave irradiation according to the following specifications: temperature: $200^{\circ} \mathrm{C}$, time (see Table 2), fixed hold time: on, sample absorption: high, pre-stirring: $60 \mathrm{~s}$. After cooling to room temperature, $\mathrm{H}_{2} \mathrm{O}(3 \mathrm{~mL})$ was added to the crude and the mixture was extracted with EtOAc $(3 \times 2 \mathrm{~mL})$. Organic layers were then washed with an aqueous saturated $\mathrm{NH}_{4} \mathrm{Cl}$ solution, dried and concentrated. The crude mixture was then purified by column chromatography on silica gel.

\section{1-(4-Methoxyphenyl)-2-phenyl-ethane-1,2-dione 2a} Yield: $75 \%$

m.p.: $65^{\circ} \mathrm{C}$

TLC: $\mathrm{R}_{\mathrm{f}} 0.40$ (Cyclohexane/EtOAc, 80/ 20, $\mathrm{SiO}_{2}$ ).

Anal. Calc. for $\mathrm{C}_{15} \mathrm{H}_{12} \mathrm{O}_{3}$ : C, 74.99; H, $5.03 \%$; Found: C, $74.81 ; \mathrm{H}, 5.21$

IR (neat) $v_{\max } / \mathrm{cm}^{-1}: 2938,2842,1666,1649,1594,1569$, $1509,1450,1422,1320,1303,1268,1214,1182,1162$, 1110, 1020, 973, 931, 877, 841, 818, 803.

${ }^{1} \mathrm{H}$ NMR for $\mathbf{2 a}\left(\mathrm{CDCl}_{3}, 200 \mathrm{MHz}, 298 \mathrm{~K}\right): \delta$, ppm 7.98$7.92(\mathrm{~m}, 4 \mathrm{H}), 7.69-7.66(\mathrm{~m}, 1 \mathrm{H}), 7.52-7.44(\mathrm{~m}, 2 \mathrm{H}), 6.96$ (d, $2 \mathrm{H}, J=9 \mathrm{~Hz}), 3.87$ (s, 3H).

${ }^{13} \mathrm{C}$ NMR for $2 \mathbf{a}\left(\mathrm{CDCl}_{3}, 50 \mathrm{MHz}, 298 \mathrm{~K}\right): \delta$, ppm 194.7 (CO), 193.0 (CO), 164.9 (C), 134.6 (CH), 133.7 (C), 132.2 $(2 \mathrm{CH}), 129.7(2 \mathrm{CH}), 128.8(2 \mathrm{CH}), 125.9(\mathrm{C}), 114.2(2 \mathrm{CH})$, $55.5\left(\mathrm{CH}_{3}\right)$.

$\mathrm{m} / \mathrm{z}$ MS (ES+) $263.1\left(\mathrm{M}+\mathrm{Na}^{+}\right)$.

\section{1-(2-Methoxyphenyl)-2-phenyl-ethane-1,2-dione $2 \mathrm{~b}$}

Yield: $70 \%$

TLC: $\mathrm{R}_{\mathrm{f}} 0.63$ (Cyclohexane/EtOAc, 85/ 15, $\mathrm{SiO}_{2}$ ).

Anal. Calc. for $\mathrm{C}_{15} \mathrm{H}_{12} \mathrm{O}_{3}$ : C, 74.99; H, $5.03 \%$; Found: C, 74.58; H, 4.95.

IR (neat) $v_{\max } / \mathrm{cm}^{-1}: 2945,1676,1654,1596,1580,1483$, $1466,1450,1435,1306,1271,1246,1202,1162,1114$, $1017,875$.

${ }^{1} \mathrm{H}$ NMR for $\mathbf{2 b}\left(\mathrm{CDCl}_{3}, 400 \mathrm{MHz}, 298 \mathrm{~K}\right): \delta$, ppm $8.06(\mathrm{~d}$, $1 \mathrm{H}, J=8.0 \mathrm{~Hz}), 7.95(\mathrm{~d}, 2 \mathrm{H}, J=8.0 \mathrm{~Hz}), 7.64-7.60(\mathrm{~m}$, $2 \mathrm{H}), 7.56(\mathrm{t}, 2 \mathrm{H}, J=8.0 \mathrm{~Hz}), 7.16(\mathrm{t}, 1 \mathrm{H}, J=8.0 \mathrm{~Hz}), 6.97$ $(\mathrm{t}, 1 \mathrm{H}, J=8.0 \mathrm{~Hz}), 3.59(\mathrm{~s}, 3 \mathrm{H})$.

${ }^{13} \mathrm{C}$ NMR for $\mathbf{2 b}\left(\mathrm{CDCl}_{3}, 100 \mathrm{MHz}, 298 \mathrm{~K}\right): \delta$, ppm 194.6 (CO), $193.5(\mathrm{CO}), 160.4(\mathrm{C}), 136.4(\mathrm{CH}), 133.7(\mathrm{CH})$, $133.0(\mathrm{C}), 130.6(\mathrm{CH}), 129.3(2 \mathrm{CH}), 128.7(2 \mathrm{CH}), 124.0$ $(\mathrm{CH}), 121.6(\mathrm{CH}), 112.4(\mathrm{CH}), 55.6\left(\mathrm{CH}_{3}\right)$. $\mathrm{m} / \mathrm{z}$ MS (ES+) $263.0\left(\mathrm{M}+\mathrm{Na}^{+}\right)$.

\section{1-(3-Methoxyphenyl)-2-phenyl-ethane-1,2-dione 2c}

Yield: $75 \%$

TLC: $\mathrm{R}_{\mathrm{f}} 0.54$ (Cyclohexane/EtOAc, 80/ 20, $\mathrm{SiO}_{2}$ ).

Anal. Calc. for $\mathrm{C}_{15} \mathrm{H}_{12} \mathrm{O}_{3}$ : C, 74.99; H, $5.03 \%$; Found: C, 
74.88; H, 4.99.

IR (neat) $v_{\max } / \mathrm{cm}^{-1}: 3074,3010,2838,1658,1592,1484$, $1467,1453,1429,1337,1321,1298,1259,1203,1174$, $1157,1079,1033,994,932,903,874,832,803$.

${ }^{1} \mathrm{H}$ NMR for $2 \mathrm{c}\left(\mathrm{CDCl}_{3}, 200 \mathrm{MHz}, 298 \mathrm{~K}\right): \delta$, ppm 7.87 (d, $1 \mathrm{H}, J=7.0 \mathrm{~Hz}), 7.58-7.49(\mathrm{~m}, 1 \mathrm{H}), 7.40-7.22(\mathrm{~m}, 5 \mathrm{H}), 7.13$ (s, 1H), 7.10-7.04 (m, 1H), $3.74(\mathrm{~s}, 3 \mathrm{H})$.

${ }^{13} \mathrm{C} \mathrm{NMR}$ for $2 \mathrm{c}\left(\mathrm{CDCl}_{3}, 50 \mathrm{MHz}, 298 \mathrm{~K}\right): \delta$, ppm 194.4 (2CO), $160.0(\mathrm{C}), 134.8(\mathrm{CH}), 134.2(\mathrm{C}), 133.0(\mathrm{C}), 130.0$ $(\mathrm{CH}), 129.8(2 \mathrm{CH}), 128.9(2 \mathrm{CH}), 123.1(\mathrm{CH}), 121.8(\mathrm{CH})$, $112.9(\mathrm{CH}), 55.4\left(\mathrm{CH}_{3}\right)$.

\section{1-Phenyl-2-(3,4,5-trimethoxyphenyl)-ethane-1,2-dione 2d}

Yield: $64 \%$

m.p.: $102{ }^{\circ} \mathrm{C}$

TLC: $\mathrm{R}_{\mathrm{f}} 0.48$ (Cyclohexane/EtOAc, 70/ 30, $\mathrm{SiO}_{2}$ ).

Anal. Calc. for $\mathrm{C}_{17} \mathrm{H}_{16} \mathrm{O}_{5}: \mathrm{C}, 67.99 ; \mathrm{H}, 5.37 \%$; Found: $\mathrm{C}$, 67.91; H, 5.30.

IR (neat) $v_{\max } / \mathrm{cm}^{-1}: 2932,2834,1664,1581,1504,1460$, $1450,1413,1343,1317,1283,1233,1180,1157,1129$, $1076,993,947,859,819$.

${ }^{1} \mathrm{H}$ NMR for $2 \mathbf{d}\left(\mathrm{CDCl}_{3}, 200 \mathrm{MHz}, 298 \mathrm{~K}\right): \delta$, ppm 7.95 (d, $2 \mathrm{H}, J=7.4 \mathrm{~Hz}), 7.66(\mathrm{t}, 1 \mathrm{H}, J=7.4 \mathrm{~Hz}), 7.49(\mathrm{t}, 2 \mathrm{H}, J=$ $7.4 \mathrm{~Hz}), 7.11$ (s, 2H), $3.93(\mathrm{~s}, 3 \mathrm{H}), 3.85(\mathrm{~s}, 6 \mathrm{H})$.

${ }^{13} \mathrm{C} \mathrm{NMR}$ for $2 \mathrm{~d}\left(\mathrm{CDCl}_{3}, 50 \mathrm{MHz}, 298 \mathrm{~K}\right): \delta$, ppm 194.2 (CO), 193.2 (CO), 153.4 (2C), 144.2 (C), $134.7(\mathrm{CH})$, 133.1 (C), $129.8(2 \mathrm{CH}), 128.9(2 \mathrm{CH}), 127.9$ (C), 107.2 $(2 \mathrm{CH}), 60.9\left(\mathrm{CH}_{3}\right), 56.3\left(2 \mathrm{CH}_{3}\right)$.

$\mathrm{m} / \mathrm{z}$ MS (ES+) $323.1\left(\mathrm{M}+\mathrm{Na}^{+}\right)$.

\section{1-(4-Methoxyphenyl)-2-(3,4,5-trimethoxyphenyl)-ethane -1,2-dione 2e}

Yield: $65 \%$

m.p.: $140{ }^{\circ} \mathrm{C}$

TLC: $\mathrm{R}_{\mathrm{f}} 0.37$ (Cyclohexane/EtOAc, 80/ 20, $\mathrm{SiO}_{2}$ ).

Anal. Calc. for $\mathrm{C}_{18} \mathrm{H}_{18} \mathrm{O}_{6}$ : C, 65.45; H, $5.49 \%$; Found: $\mathrm{C}$, 65.46; H, 5.59.

IR (neat) $v_{\max } / \mathrm{cm}^{-1}: 2982,1651,1598,1571,1502,1448$, 1427,1412 , 1342, 1273, 1245, 1180, 1155, 1125, 1017, $998,948,854$.

${ }^{1} \mathrm{H}$ NMR for $2 \mathrm{e}\left(\mathrm{CDCl}_{3}, 200 \mathrm{MHz}, 298 \mathrm{~K}\right): \delta$, ppm 7.95 (d, $2 \mathrm{H}, J=9.0 \mathrm{~Hz}), 7.23(\mathrm{~s}, 2 \mathrm{H}), 6.98(\mathrm{~d}, 2 \mathrm{H}, J=9 \mathrm{~Hz}), 3.94$ (s, 3H), $3.89(\mathrm{~s}, 3 \mathrm{H}), 3.88(\mathrm{~s}, 6 \mathrm{H})$.

${ }^{13} \mathrm{C}$ NMR for $2 \mathrm{e}\left(\mathrm{CDCl}_{3}, 50 \mathrm{MHz}, 298 \mathrm{~K}\right): \delta$, ppm 193.5 (CO), 192.8 (CO), 164.9 (C), 153.2 (2C), 144.1 (C), 132.3 $(2 \mathrm{CH}), 128.1(\mathrm{C}), 126.1(\mathrm{C}), 114.3(2 \mathrm{CH}), 107.2(2 \mathrm{CH})$, $60.9\left(\mathrm{CH}_{3}\right), 56.3\left(2 \mathrm{CH}_{3}\right), 55.5\left(\mathrm{CH}_{3}\right)$.

$\mathrm{m} / z \mathbf{M S}(\mathrm{ES}+) 353.1\left(\mathrm{M}+\mathrm{Na}^{+}\right)$.

\section{1-Phenyl-2-p-tolyl-ethane-1,2-dione $2 \mathrm{f}$}

Yield: $61 \%$

m.p.: $96^{\circ} \mathrm{C}$

TLC: $\mathrm{R}_{\mathrm{f}} 0.51$ (Cyclohexane/EtOAc, 90/ 10, $\mathrm{SiO}_{2}$ ).

Anal. Calc. for $\mathrm{C}_{14} \mathrm{H}_{10} \mathrm{O}_{2}$ : C, 79.98; H, $4.79 \%$; Found: C, $79.92 ; \mathrm{H}, 4.81$
IR (neat) $v_{\max } / \mathrm{cm}^{-1}: 1665,1591,1578,1449,1325,1209$, 1173, 998, 874.

${ }^{1} \mathrm{H}$ NMR for $2 \mathbf{f}\left(\mathrm{CDCl}_{3}, 200 \mathrm{MHz}, 298 \mathrm{~K}\right): \delta$, ppm 7.97 (d, $4 \mathrm{H}, J=8.0 \mathrm{~Hz}), 7.67(\mathrm{~m}, 2 \mathrm{H}), 7.52(\mathrm{~d}, 4 \mathrm{H}, J=8.0 \mathrm{~Hz})$.

${ }^{13} \mathrm{C} \mathrm{NMR}$ for $2 \mathrm{f}\left(\mathrm{CDCl}_{3}, 50 \mathrm{MHz}, 298 \mathrm{~K}\right): \delta$, ppm 194.0 (2CO), $134.7(2 \mathrm{CH}), 132.9(2 \mathrm{CH}), 129.8(4 \mathrm{CH}), 128.9$ (4CH).

$m / z$ MS (ES+) $233.0\left(\mathrm{M}+\mathrm{Na}^{+}\right)$.

\section{1,2-Diphenyl-ethane-1,2-dione (Benzil) 2g}

Yield: $73 \%$

TLC: $\mathrm{R}_{\mathrm{f}} 0.27$ (Cyclohexane/EtOAc, 90/ 10, $\mathrm{SiO}_{2}$ ).

Anal. Calc. for $\mathrm{C}_{15} \mathrm{H}_{12} \mathrm{O}_{2}$ : C, 80.34; H, $5.39 \%$; Found: C, 80.26; H, 5.31.

IR (neat) $v_{\max } / \mathrm{cm}^{-1}: 1667,1603,1572,1475,1449,1410$, 1324, 1287, 1208, 1173, 1120, 1019, 879, 828.

${ }^{1} \mathrm{H}$ NMR for $\mathbf{2 g}\left(\mathrm{CDCl}_{3}, 200 \mathrm{MHz}, 298 \mathrm{~K}\right): \delta$, ppm $7.96(\mathrm{~d}$, $2 \mathrm{H}, J=7.3 \mathrm{~Hz}), 7.86(\mathrm{~d}, 2 \mathrm{H}, J=8.0 \mathrm{~Hz}), 7.64(\mathrm{t}, 1 \mathrm{H}, J=$ $7.3 \mathrm{~Hz}), 7.49(\mathrm{t}, 2 \mathrm{H}, J=7.3 \mathrm{~Hz}), 7.30(\mathrm{~d}, 2 \mathrm{H}, J=8 \mathrm{~Hz})$, $2.42(\mathrm{~s}, 3 \mathrm{H})$.

${ }^{13} \mathrm{C} \mathrm{NMR}$ for $2 \mathrm{~g}\left(\mathrm{CDCl}_{3}, 50 \mathrm{MHz}, 298 \mathrm{~K}\right): \delta$, ppm 194.7 (CO), 194.2 (CO), 146.1 (C), $134.7(\mathrm{CH}), 133.1$ (C), 130.6 (C), $129.9(2 \mathrm{CH}), 129.8(2 \mathrm{CH}), 129.7(2 \mathrm{CH}), 128.9(2 \mathrm{CH})$, $21.8\left(\mathrm{CH}_{3}\right)$.

\section{1-(4-Chlorophenyl)-2-phenyl-ethane-1,2-dione $2 \mathrm{~h}$}

Yield: $75 \%$

m.p.: $77^{\circ} \mathrm{C}$

TLC: $\mathrm{R}_{\mathrm{f}} 0.35$ (Cyclohexane/EtOAc, 70/ 30, $\mathrm{SiO}_{2}$ ).

Anal. Calc. for $\mathrm{C}_{14} \mathrm{H}_{9} \mathrm{ClO}_{2}$ : C, 68.72; $\mathrm{H}, 3.71 \%$; Found: $\mathrm{C}$, $69.01 ; \mathrm{H}, 3.75$.

IR (neat) $v_{\max } / \mathrm{cm}^{-1}: 1663,1584,1487,1450,1402,1321$, $1208,1172,1113,1093,1013,873,833$.

${ }^{1} \mathrm{H}$ NMR for $\mathbf{2 h}\left(\mathrm{CDCl}_{3}, 200 \mathrm{MHz}, 298 \mathrm{~K}\right): \delta$, ppm 7.987.90 (m, 3H), 7.70-7.63 (m, 2H), 7.55-7.40 (m, 4H).

${ }^{13} \mathrm{C}$ NMR for $\mathbf{2 h}\left(\mathrm{CDCl}_{3}, 50 \mathrm{MHz}, 298 \mathrm{~K}\right): \delta$, ppm 193.8 (CO), $193.0(\mathrm{CO}), 141.5(\mathrm{C}), 135.0(\mathrm{CH}), 132.8(\mathrm{C}), 131.4$ (C), $131.2(2 \mathrm{CH}), 129.9(2 \mathrm{CH}), 129.4(2 \mathrm{CH}), 129.0(2 \mathrm{CH})$.

\section{1-(4-Bromophenyl)-2-phenyl-ethane-1,2-dione 2i}

Yield: $72 \%$

m.p.: $87^{\circ} \mathrm{C}$

TLC: $\mathrm{R}_{\mathrm{f}} 0.61$ (Cyclohexane/EtOAc, 94/ 6, $\mathrm{SiO}_{2}$ ).

Anal. Calc. for $\mathrm{C}_{14} \mathrm{H}_{9} \mathrm{BrO}_{2}$ : C, 58.16; H, $3.14 \%$; Found: $\mathrm{C}$, 58.02; H, 3.03.

IR (neat) $v_{\max } / \mathrm{cm}^{-1}: 1662,1578,1483,1450,1398,1321$, 1204, 1172, 1113, 1069, 1024, 1009, 870, 829.

${ }^{1} \mathrm{H}$ NMR for $2 \mathbf{i}\left(\mathrm{CDCl}_{3}, 200 \mathrm{MHz}, 298 \mathrm{~K}\right): \delta$, ppm $7.96(\mathrm{~d}$, $2 \mathrm{H}, J=7.4 \mathrm{~Hz}), 7.84(\mathrm{~d}, 2 \mathrm{H}, J=8.6 \mathrm{~Hz}), 7.68-7.64(\mathrm{~m}$, $3 \mathrm{H}), 7.52(\mathrm{t}, 2 \mathrm{H}, J=7.4 \mathrm{~Hz})$.

${ }^{13} \mathrm{C}$ NMR for $2 \mathbf{i}\left(\mathrm{CDCl}_{3}, 50 \mathrm{MHz}, 298 \mathrm{~K}\right)$ : $\delta$, ppm 193.8 (CO), 193.2 (CO), $135.0(\mathrm{CH}), 132.8(\mathrm{C}), 132.4(2 \mathrm{CH})$, 131.8 (C), $131.2(2 \mathrm{CH}), 130.4(\mathrm{C}), 129.9(2 \mathrm{CH}), 129.0$ $(2 \mathrm{CH})$

1-(4-Nitrophenyl)-2-phenyl-ethane-1,2-dione $2 \mathrm{j}$ 
Yield: $72 \%$

m.p.: $141{ }^{\circ} \mathrm{C}$

TLC: $\mathrm{R}_{\mathrm{f}} 0.27$ (Cyclohexane/EtOAc, 50/ 50, $\mathrm{SiO}_{2}$ ).

Anal. Calc. for $\mathrm{C}_{14} \mathrm{H}_{9} \mathrm{NO}_{4}$ : C, 65.88; H, 3.55; N, $5.49 \%$; Found: C, 65.81; H, 3.54; N, 5.48.

IR (neat) $v_{\max } / \mathrm{cm}^{-1}: 1660,1594,1523,1450,1344,1200$, $1170,1110,883,859,839$.

${ }^{1} \mathrm{H}$ NMR for $\mathbf{2 j}\left(\mathrm{CDCl}_{3}, 200 \mathrm{MHz}, 298 \mathrm{~K}\right): \delta$, ppm $8.36(\mathrm{~d}$, $2 \mathrm{H}, J=8.7 \mathrm{~Hz}), 8.17(\mathrm{~d}, 2 \mathrm{H}, J=8.7 \mathrm{~Hz}), 7.99(\mathrm{dd}, 2 \mathrm{H}, J=$ $7.9 \mathrm{~Hz}, J=1.0 \mathrm{~Hz}), 7.71(\mathrm{tt}, 1 \mathrm{H}, J=7.9 \mathrm{~Hz}, J=1.0 \mathrm{~Hz})$, $7.55(\mathrm{t}, 2 \mathrm{H}, J=7.9 \mathrm{~Hz})$.

${ }^{13} \mathrm{C}$ NMR for $\mathbf{2 j}\left(\mathrm{CDCl}_{3}, 50 \mathrm{MHz}, 298 \mathrm{~K}\right)$ : $\delta$, ppm 192.8 (CO), 192.0 (CO), $151.1(\mathrm{C}), 137.3(\mathrm{C}), 135.4(\mathrm{CH}), 132.4$ (C), $130.9(2 \mathrm{CH}), 130.0(2 \mathrm{CH}), 129.2(2 \mathrm{CH}), 129.0(2 \mathrm{CH})$.

\section{1-(4-Cyanophenyl)-2-phenyl-ethane-1,2-dione 2k}

Yield: $46 \%$

m.p.: $111.5^{\circ} \mathrm{C}$

TLC: $\mathrm{R}_{\mathrm{f}} 0.42$ (Cyclohexane/EtOAc, 90/ 10, $\mathrm{SiO}_{2}$ ).

Anal. Calc. for $\mathrm{C}_{15} \mathrm{H}_{9} \mathrm{NO}_{2}$ : C, 76.59; H, 3.86; N, $5.95 \%$; Found: C, 76.38; H, 3.61; N, 5.85.

IR (neat) $v_{\max } / \mathrm{cm}^{-1}: 3072,2226,1679,1658,1593,1579$, 1450, 1405, 1321, 1297, 1206, 1171, 1116, 999, 971, 879, $843,800$.

${ }^{1} \mathrm{H}$ NMR for $\mathbf{2 k}\left(\mathrm{CDCl}_{3}, 200 \mathrm{MHz}, 298 \mathrm{~K}\right): \delta$, ppm 8.08 (d, $2 \mathrm{H}, J=8.0 \mathrm{~Hz}), 7.96(\mathrm{~d}, 2 \mathrm{H}, J=8.6 \mathrm{~Hz}), 7.80(\mathrm{~d}, 2 \mathrm{H}, J=$ $8.6 \mathrm{~Hz}), 7.69$ (t, $1 \mathrm{H}, J=8.0 \mathrm{~Hz}), 7.53(\mathrm{t}, 2 \mathrm{H}, J=8.0 \mathrm{~Hz})$.

${ }^{13} \mathrm{C} \mathrm{NMR}$ for $2 \mathbf{k}\left(\mathrm{CDCl}_{3}, 50 \mathrm{MHz}, 298 \mathrm{~K}\right)$ : $\delta$, ppm 193.0 (CO), 192.4 (CO), 135.9 (C), $135.3(\mathrm{CH}), 132.7$ (C), 132.5 $(2 \mathrm{CH}), 130.2(2 \mathrm{CH}), 130.0(2 \mathrm{CH}), 129.2(2 \mathrm{CH}), 117.9(\mathrm{C})$, $117.5(\mathrm{C})$

\section{2-(2-Oxo-2-phenylacetyl)-benzonitrile 2l}

Yield: $43 \%$

m.p.: $67.5^{\circ} \mathrm{C}$

TLC: $\mathrm{R}_{\mathrm{f}} 0.36$ (Cyclohexane/EtOAc, 70/ 30, $\mathrm{SiO}_{2}$ ).

Anal. Calc. for $\mathrm{C}_{15} \mathrm{H}_{9} \mathrm{NO}_{2}: \mathrm{C}, 76.59 ; \mathrm{H}, 3.86 ; \mathrm{N}, 5.95 \%$; Found: C, 76.47; H, 3.79; N, 5.92.

IR (neat) $v_{\max } / \mathrm{cm}^{-1}: 3067,2926,2227,1668,1592,1570$, 1489, 1451, 1367, 1318, 1212, 1180, 1124, 1017, 951, 888, 869.

${ }^{1} \mathrm{H}$ NMR for $2 \mathrm{l}\left(\mathrm{CDCl}_{3}, 400 \mathrm{MHz}, 298 \mathrm{~K}\right): \delta$, ppm 8.05 (d, $2 \mathrm{H}, J=8.4 \mathrm{~Hz}), 7.96-7.92(\mathrm{~m}, 2 \mathrm{H}), 7.82-7.71(\mathrm{~m}, 3 \mathrm{H}), 7.58$ (t, $2 \mathrm{H}, J=8.4 \mathrm{~Hz})$.

${ }^{13} \mathrm{C}$ NMR for $2 \mathrm{l}\left(\mathrm{CDCl}_{3}, 50 \mathrm{MHz}, 298 \mathrm{~K}\right): \delta$, ppm 192.1 (CO), $191.2(\mathrm{CO}), 135.6(\mathrm{CH}), 135.3(\mathrm{CH}), 135.1(\mathrm{C})$, $134.0(\mathrm{CH}), 132.7(\mathrm{CH}), 132.4(\mathrm{C}), 132.3(\mathrm{CH}), 130.1$ $(2 \mathrm{CH}), 129.1(2 \mathrm{CH}), 117.0(\mathrm{C}), 117.9(\mathrm{CN}), 112.0(\mathrm{C})$.

\section{1-(4-Hydroxyphenyl)-2-phenyl-ethane-1,2-dione 2m}

Yield: $51 \%$

m.p.: $125^{\circ} \mathrm{C}$

TLC: $\mathrm{R}_{\mathrm{f}} 0.50$ (Cyclohexane/EtOAc, 70/ 30, $\mathrm{SiO}_{2}$ ).

Anal. Calc. for $\mathrm{C}_{14} \mathrm{H}_{10} \mathrm{O}_{3}$ : C, 74.33; H, $4.46 \%$; Found: C, $74.18 \mathrm{H}, 4.32$.

IR (neat) $v_{\text {max }} / \mathrm{cm}^{-1}: 3385,1672,1648,1595,1562,1515$, 1449, 1302, 1204, 1157, 1047, 998, 878, 845.

${ }^{1} \mathrm{H}$ NMR for $\mathbf{2 m}\left(\mathrm{CDCl}_{3}, 400 \mathrm{MHz}, 298 \mathrm{~K}\right): \delta$, ppm 7.88 $(\mathrm{d}, 2 \mathrm{H}, J=7.3 \mathrm{~Hz}), 7.80(\mathrm{~d}, 2 \mathrm{H}, J=8.6 \mathrm{~Hz}), 7.57(\mathrm{t}, 1 \mathrm{H}, J$ $=7.3 \mathrm{~Hz}), 7.42(\mathrm{t}, 2 \mathrm{H}, J=7.3 \mathrm{~Hz}), 6.82(\mathrm{~d}, 2 \mathrm{H}, J=8.6 \mathrm{~Hz})$, 6.80-6.10 (m, 1H).

${ }^{13} \mathrm{C} \mathrm{NMR}$ for $\mathbf{2 m}\left(\mathrm{CDCl}_{3}, 50 \mathrm{MHz}, 298 \mathrm{~K}\right): \delta$, ppm 195.4 (CO), $193.6(\mathrm{CO}), 162.5(\mathrm{C}), 135.0(\mathrm{CH}), 133.0(\mathrm{C}), 132.7$ $(2 \mathrm{CH}), 129.9(2 \mathrm{CH}), 129.0(2 \mathrm{CH}), 125.6(\mathrm{C}), 116.1(2 \mathrm{CH})$

\section{2,2-Dimethyl-propionic acid 4-(2-oxo-2phenyl-acetyl)- phenyl ester 20}

Yield: $59 \%$

m.p.: $87^{\circ} \mathrm{C}$

TLC: $\mathrm{R}_{\mathrm{f}} 0.47$ (Cyclohexane/EtOAc, 90/ 10, $\mathrm{SiO}_{2}$ ).

Anal. Calc. for $\mathrm{C}_{19} \mathrm{H}_{18} \mathrm{O}_{4}$ : C, 73.53; H, $5.85 \%$; Found: C, $73.41 ; \mathrm{H}, 5.79$.

IR (neat) $v_{\max } / \mathrm{cm}^{-1}: 2978,1742,1662,1594,1505,1479$, $1454,1400,1366,1326,1296,1280,1231,1207,1174$, 1157, 1116, 1032, 1012, 997, 974, 904, 873, 804.

${ }^{1} \mathrm{H}$ NMR for $20\left(\mathrm{CDCl}_{3}, 400 \mathrm{MHz}, 298 \mathrm{~K}\right): \delta$, ppm 8.05$7.94(\mathrm{~m}, 4 \mathrm{H}), 7.65(\mathrm{tt}, 1 \mathrm{H}, J=7.7 \mathrm{~Hz}, J=1.4 \mathrm{~Hz}), 7.54-$ $7.46(\mathrm{~m}, 2 \mathrm{H}), 7.26-7.16(\mathrm{~m}, 2 \mathrm{H})$.

${ }^{13} \mathrm{C}$ NMR for $20\left(\mathrm{CDCl}_{3}, 50 \mathrm{MHz}, 298 \mathrm{~K}\right): \delta$, ppm 194.2 (CO), 193.2 (CO), 176.2 (OCO), $156.3(\mathrm{C}), 134.9(\mathrm{CH})$, $132.9(\mathrm{C}), 131.5(2 \mathrm{CH}), 130.3(\mathrm{C}), 129.9(2 \mathrm{CH}), 129.0$ $(2 \mathrm{CH}), 122.2(2 \mathrm{CH}), 93.2(\mathrm{C}), 27.0\left(3 \mathrm{CH}_{3}\right)$.

\section{Acknowledgments}

The CNRS is gratefully acknowledged for support of this research and the MNSER for a doctoral fellowship to AG. The authors wishes also to thank Pr. T. Besson for fruitful discussions concerning the use of DMSO under MW irradiations.

\section{References}

\footnotetext{
${ }^{1}$ Ita, B. I.; Offiong, O. E. Mater. Chem. Phys. 2001, 70, 330.

2 Matsuschita Electric Industrial Co Ltd., Jpn. Kokai Tokkyo Koho, 1981, 203, 8198; Chem. Abstr. 1981, 95, $188163 \mathrm{u}$.
}

3 (a) Mahabusarakam, W.; Deachathai, S.; Phongpaichit, S.; Jansakul, C.; Taylor, W. C. Phytochemistry, 2004, 65, 1185. (b) Hillis, L. R.; Ronald, R. C. J. Org. Chem. 1985, 45, 2741. (c) Rozwadowska, M. D.; Chrzanowska, M. Tetrahedron, 1985, 41, 2885. (d) Re, L.; Maurer, B.; Ohloff, G. Helv. Chim. Acta 1973, 56, 1882.

4 (a) Wolkenberg, S. E.; Wisnoski, D. D.; Leister, W. H.; Wang, Y.; Zhao, Z.; Lindsley, C. L. Org. Lett. 2004, 6, 1453. (b) Deng, X.; Mani, N. Org. Lett. 2006, 8, 269.

5 (a) Bhosale, R. S.; Sarda, S. R.; Ardhapure, S. S.; Jadhav, W. N.; Bhusare, S. R.; Pawar, R. P. Tetrahedron Lett. 2005, 46, 7183. (b) Hui, X.; Desrivot, J.; Bories, C.; Loiseau, P. M., Franck, X.; Hocquemiller, R.; Figadère, B. Bioorg. Med. Chem. 2006, 16, 815.

${ }^{6}$ (a) Clarke, H. T.; Dreger, E. E. Org. Synth. Coll. Vol. 1 1941, 87. (b) Rigby, W. J. J. Chem. Soc. 1951, 793. (c) 
Fieser, L. F.; Fieser, M. Reagents for Organic Synthesis; John Wiley and Sons: New York, 1967; Vol. 1 p1. (d) McKillop, A.; Swann, B.; Ford, M. E.; Taylor, E. C. J. Am. Chem. Soc. 1973, 95, 3641. (e) Zhang, G.-S.; Shi, Q.-Z.; Chen, M.-F.; Cai, K. Synth. Commun. 1997, 27, 953. (f) Okimoto, M.; Takahashi, Y.; Nagata, Y.; Sasaki, G.; Numata, K. Synthesis 2005, 705. (g) Baskaran, S.; Das, J.; Chandrasekaran, S. J. Org. Chem. 1989, 54, 5182.

7 (a) Khurana, J. M.; Kandpal, B. M. Tetrahedron Lett. 2003, 44, 4909. (b) Anelli, P. L.; Banfi, S.; Montanari, F.; Quici, S. J. Org. Chem. 1989, 54, 2970. (c) Iwahama, T.; Sakaguchi, S.; Nishiyama, Y.; Ishii, Y. Tetrahedron Lett. 1995, 36, 6923.

8 (a) Antoniotti, S.; Duñach, E. Eur. J. Org. Chem. 2004, 3459. (b) Clayton, M. D.; Marcinow, Z.; Rabineau, P. W. Tetrahedron Lett. 1998, 39, 9127. (c) Corey, E. J.; Lee, D.H.; Sarshar, S. Tetrahedron: Asymmetry. 1995, 6, 3. (d) Yusybov, M. S.; Filimonov, V. D. Synthesis 1991, 131.

9 Li, P.; Cheong, F. H.; Chao, L. C. F.; Lin, Y. H.; Williams, I. D. J. Mol. Catal. 1999, 145, 111.

10 Firouzabadi, H.; Sardarian, A. R.; Moosavipour, H.; Afshari, G. M. Synthesis 1986, 285.

11 Rogatchov, V. O.; Filimonov, V. D.; Yusubov, M. S. Synthesis 2001, 1001.

12 Gebeyehu, G.; McNelis, E. J. Org. Chem. 1980, 45, 4280.

${ }^{13}$ Zhu, Z.; Espenson, J. H. J. Org. Chem. 1985, 60, 7728.

${ }^{14}$ Wolfe, S.; Pilgrim, W. R.; Garrard, T. F.; Chamberlain, P. Can. J. Chem. 1971, 49, 1099.

15 Yubusov, M. S.; Filimonov, V. D. Synth. Commun. 1994, 24, 2119. (b) Yubusov, M. S.; Krasnokutskaya, E. A.; Vasilyeva, V. P.; Filimonov, V. D.; Chi, K.-W. Bull. Korean Chem. Soc. 1995, 16, 86.

16 Yusubov, M. S.; Zholobova, G. A.; Vasilevsky, S. F.; Tretyakov, E. V.; Knight, D. W. Tetrahedron 2002, 58, 1607.

${ }^{17}$ Wan, Z.; Jones, C. D.; Mitchell, D.; Pu, J. Y.; Zhang, T. Y. J. Org. Chem. 2006, 71, 826.

18 (a) Bekaert, A.; Barberan, A.; Gervais, M.; Brion, J. D. Tetrahedron Lett. 2000, 41, 2903. (b) Berrien, J. F.; Provot, O.; Joseph, D.; Bekaert, A. J. Chem. Educ. 2004, 81, 1348. (c) Bekaert, A.; Provot, O.; Rasolojahona, O.; Alami, M.; Brion, J. D. Tetrahedron Lett. 2005, 46, 4187. (d) Le Bras, G.; Provot, O.; Bekaert, A.; Peyrat, J. F.; Alami, M.; Brion, J. D. Synthesis 2006, in press.

${ }^{19}$ For reproductibility considerations, three identical tests have been achieved using the microwave automaton and isolated yields were similar $( \pm 4 \%)$.

${ }^{20}$ Alami, M.; Ferri, F.; Linstrumelle, G. Tetrahedron Lett. 1993, 34, 1433.

${ }^{21}$ Mésangeau, C.; Yous; S.; Pérès, B.; Lesieur, D.; Besson, T. Tetrahedron Lett. 2005, 46, 2465.

${ }^{22}$ Haynes, J. S.; Sams, J. R.; Thomson, R. C. Can. J. Chem. 1981, 59, 669. 